\title{
A new species of stalked crinoid (Echinodermata) of possible Late Silurian age from central Newfoundland
}

\author{
S.K. Donovan 1, W.L. Dickson ${ }^{2}$, W.D. Boyce ${ }^{2}$, and J.S. Ash ${ }^{2}$ \\ 1 Department of Geology, University of the West Indies, Mona, Kingston 7, Jamaica \\ ${ }^{2}$ Geological Survey, Newfoundland and Labrador Department of Mines and Energy, \\ P. O. Box 8700, St. John's, Newfoundland A1B 4J6, Canada
}

Date Received May 20, 1996

Date Accepted August 7, 1996

\begin{abstract}
A new fossil locality within a sequence previously assigned to the Middle Ordovician Baie D'Espoir Group in south-central Newfoundland contains fragmented crinoid columnals and brachiopods. Distinctive, pentastellate crinoid columnals, similar to those assigned to the monobathrid camerate Hexacrinites Austin and Austin by Russian authors, are named Hexacrinites? pentastellatus $\mathrm{n}$. sp. Nodal(?) columnals of this species have a circular, depressed articular facet, with a conical to bowl-like crenularium, a depressed, circular areola, a raised perilumen and a short, slender axial canal of pentagonal section. The oldest Hexacrinites sensu stricto are Late Silurian, suggesting that the fossiliferous strata have been incorrectly assigned to the Ordovician. Cross-sections of brachiopods from the same locality include an example that resembles several Early Silurian to Late Devonian pentameroid genera including Brooksina Kirk, 1922. Correlation with Late Silurian, bivalve-bearing strata $50 \mathrm{~km}$ to the northeast would indicate that a major unconformity may occur above the fossiliferous Early and Middle Ordovician strata and the Early Ordovician ophiolite complexes.
\end{abstract}

Un nouvel emplacement de fossiles à l'intérieur d'une séquence auparavant attribuée au groupe de l'Ordovicien moyen de Baie d'Espoir dans le centre-sud de Terre-Neuve renferme des fragments de columnales et de brachiopodes de crinoïdes. Des columnales de crinoïdes pentaétoilées caractéristiques, semblables à celles attribuées à l'Hexacrinites Austin and Austin à loges monobathrides par des auteurs russes, sont baptisées nouvelle espèce pentastellatus d'Hexacrinites?. Les columnales nodales(?) de cette espèce sont pourvues d'une facette articulaire renfoncée et circulaire munie d'un crénularium allant de conique à bombé, d'une aréole circulaire renfoncée, d'un périlumen surélevé et d'un canal axial mince et court de section pentagonale. Les plus anciens Hexacrinites, au sens strict, remontent au Silurien supérieur, ce qui permet de supposer qu'on a incorrectement attribué la strate fossilifère à l'Ordovicien. Des échantillons représentatifs de brachiopodes-du même emplacement comprennent un exemple qui ressemble à plusieurs genres de pentaméroïdes datant du Silurien inférieur au Dévonien supérieur, notamment le Brooksina Kirk, 1922. Leur corrélation avec des strates renfermant des bivalves du Silurien supérieur à $50 \mathrm{~km}$ au nord-est signale qu'une discordance importante pourrait se présenter au-dessus des strates fossilifères de l'Ordovicien inférieur ou moyen de même que des complexes d'ophiolites de l'Ordovicien inférieur.

[Traduit par la rédaction]

\section{INTRODUCTION}

The geology of south-central Newfoundland is complex. The main components are Lower Ordovician, or older, shelffacies, quartz-rich sandstone of the Spruce Brook Formation that has been overthrust by ophiolites of the Late Cambrian to Early Ordovician Coy Pond and Great Bend complexes. Various Ordovician sedimentary and volcanic units are juxtaposed with the ophiolite complexes along major faults. Silurian volcanic and sedimentary rocks locally, unconformably overlie or are in fault contact with the older strata. The assignment of ages to the various sedimentary strata and, therefore, their correlation has depended on the few fossil localities. Recent radiometric age determinations on the various granitic, gabbroic and felsic volcanic rocks in the area have provided new insights, and revolutionized the understanding of the orogenic history of the area (Dunning et al., 1990).
South-central Newfoundland contains few fossil localities and until recently only some had been studied in detail. Trilobite, brachiopod and graptolite localities have received most attention, and precise stratigraphic data generally indicating Early and Middle Ordovician ages have been obtained (e.g., Colman-Sadd and Swinden, 1984; Boyce, 1987; Boyce et al., 1988, 1993a; Williams, 1991, 1993; Williams et al., 1992). Localities containing mainly crinoids, bryozoa, and corals and a few brachiopods have only rarely been examined in detail. Some have been determined to be Early Silurian in age (e.g., Williams, 1972) whereas others have been assumed to be Silurian (e.g., Anderson and Williams, 1970; Williams, 1972; Blackwood, 1982) (Fig. 1).

Recently, in the Careless Brook area, $50 \mathrm{~km}$ northeast of fossil locality 91 F001 (Fig. 1), a previously known fossiliferous section that had been correlated with Wenlockian brachiopod-rich strata was discovered to contain many more fossil occurrences and a much more diverse fauna than pre- 


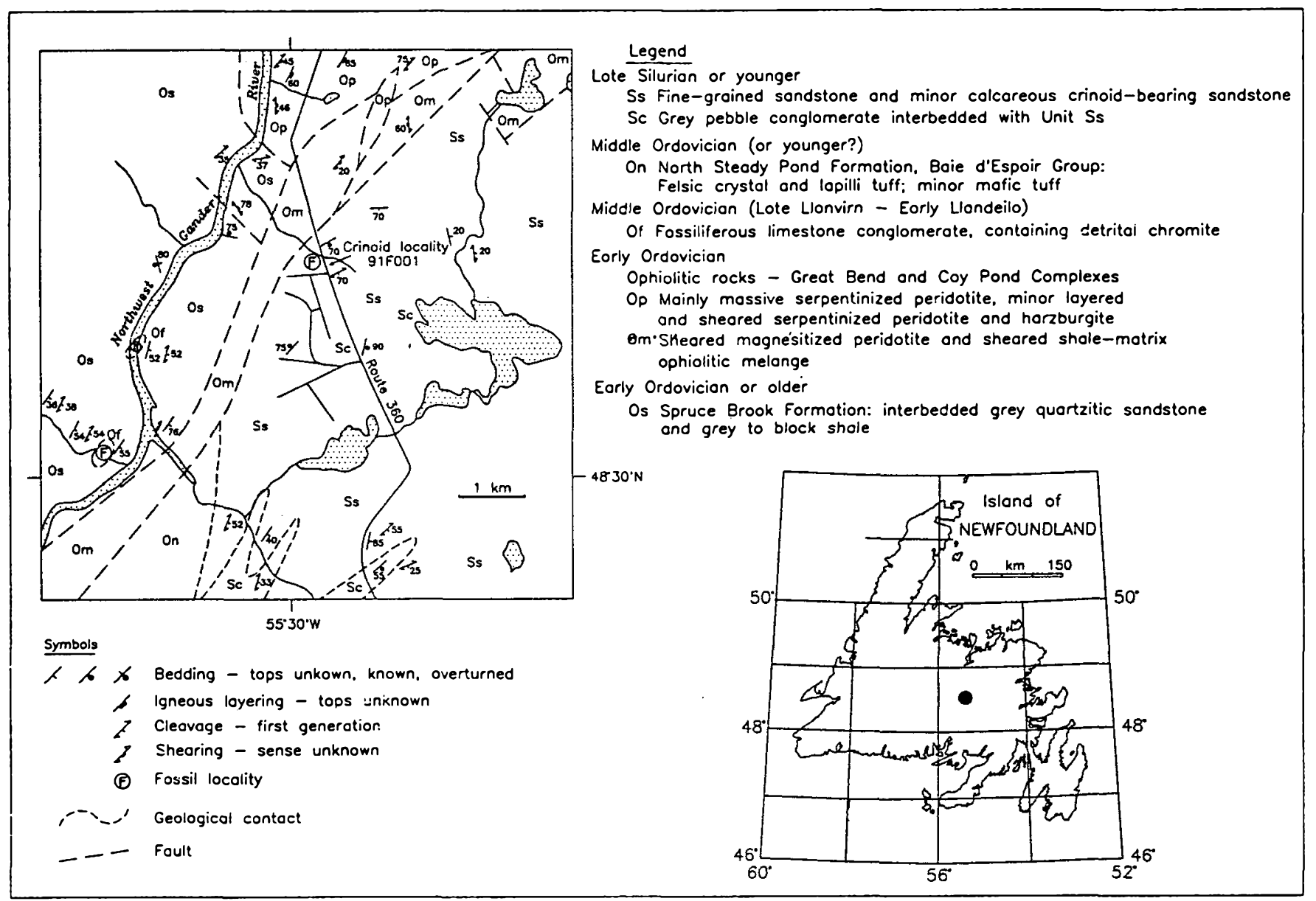

Fig. 1. Geology of the area around fossil locality 91F001, Northwest Gander River area. Geology from Blackwood (1983), ColmanSadd (1985), Colman-Sadd and Russell (1988), Dec and Colman-Sadd (1990), and Dickson (1992). Inset map shows the location of the Northwest Gander River area in central Newfoundland.

viously reported. Four bivalve-rich horizons collectively yielded the following taxa (Boyce et al., 1993b; Boyce and Ash, 1994):

\section{Arthropoda-?Eurypterida}

Gen. et sp. indet. (fragments)

Arthropoda-Trilobita

Homalonotus / Trimerus sp. indet. (cranidium)

Brachiopoda-Articulata

Gen. et $s p(p)$. indet.

Echinodermata-Crinoidea

Gen. et sp. indet. (columnals)

Mollusca-Bivalvia

Cuneamya arata (Hall, 1860)

Goniophora consimilis Billings, 1874

Grammysia sp. cf. G. macadamensis McLearn, 1924

Modiolopsis sp. indet.

Mytilarca amii McLearn, 1924

Orthonota simulans Billings, 1874

Orthonota venusta Billings, 1874

Palaeoneilo attenuata (Hall, 1860)

Mollusca-Gastropoda

Gen. et sp. indet.
The bivalves together indicate a Late Silurian (Pridolian) to possibly Early Devonian (Gedinnian) age (Boyce $e t$ al., 1993b; Boyce and Ash, 1994). The lower parts of the sequence contain a variety of fossiliferous horizons containing crinoids, corals, bryozoa, articulate brachiopods and one horizon rich in trace fossils. The host rocks are mainly medium-bedded sandstone that are steeply dipping and massive to weakly cleaved.

In 1991, a previously undiscovered outcrop of buff, medium-bedded, cleaved sandstone was found to contain one $12-\mathrm{cm}$-thick horizon of fossiliferous calcareous sandstone (Fig. 1). The fossils are mainly crinoids, with rare brachiopods and bryozoa (Dickson, 1992). This outcrop lies within strata that had been correlated with the Middle Ordovician North Steady Pond Formation of the Baie D'Espoir Group or the stratigraphically equivalent Davidsville Group by ColmanSadd and Swinden (1984). The presence of the abundant crinoid debris is unusual for the known Ordovician strata in the area and was taken to indicate a possible Silurian age for the strata (Dickson, 1992) by comparison with other assumed Silurian crinoid-bearing strata.

Blackwood (1983) indicated that nearby strata containing extensive pebble conglomerate units were also possibly 
of Silurian age. These conglomerates contain clasts of chert, slate, cleaved siltstone and sandstone, feldspar porphyry and leucogabbro. Similar conglomerates occur along strike from the crinoid-bearing locality. The clasts are similar to the rock types of the nearby Lower and Middle Ordovician strata.

This paper represents one of the first attempts to identify crinoid columnals using Newfoundland material and to determine the age of the containing strata. Silurian fossils in this area would greatly extend the distribution of Silurian strata in central Newfoundland and must result in a reassessment of the stratigraphy and possibly the tectonic history of the region.

Terminology of the crinoid stem used herein follows Moore et al . (1968) and Ubaghs (1978a). The recommendations of Bengtson (1988, page 226), concerning the use of open nomenclature where taxonomic assignment requires caution, are followed herein. Columnal morphogeneric names are followed by the suffix (col.) as recommended by Stukalina (1968). The specimens described herein are deposited in the collections of the Newfoundland Museum, St. John's.

\section{Material AND METHOdS}

Four blocks, numbered NGS [1-4], contain abundant debris from pelmatozoan columns, most (but not necessarily all) fragments being derived from the species described herein. These blocks were partially decalcified using 5 to $10 \%$ hydrochloric acid to produce external moulds; NGS [1] was broken into fragments to facilitate examination. Latex casts were taken from the external moulds thus produced. Moulds (Plate 1) and latex casts (Plate 2) were mounted on aluminum stubs using double-sided adhesive tape or white "Elmers" glue, coated with $60 \%$ gold-palladium and examined using a Philips 501B scanning electron microscope (SEM). Other blocks from the same locality were not decalcified.

\section{Systematic Palaeontology}

Class CRINOIDEA J.S. Miller Order MONOBATHRIDA Moore and Laudon Family HEXACRINITIDAE Wachsmuth and Springer

\section{Genus Hexacrinites Austin and Austin}

Type species: Platycrinus interscapularis Phillips, 1841, p. 28, by monotypy (Austin and Austin, 1843, p. 19; Ubaghs, 1978b, p. T473).

\section{Diagnosis: See Ubaghs (1978b, pp. T473, T475).}

Remarks: Stellate pelmatozoan columnals are known from at least as early as the Late Ordovician (see, for example, Donovan, 1986, plate 4, figure 3; Pisera, 1994, plate 63, figure 6; Donovan, 1995, text-figure 46A). However, Paleozoic crinoids with such well-developed and inflated, stellate epifacets as are seen in the Newfoundland species are only known to occur from the Early Silurian to the Early Per-
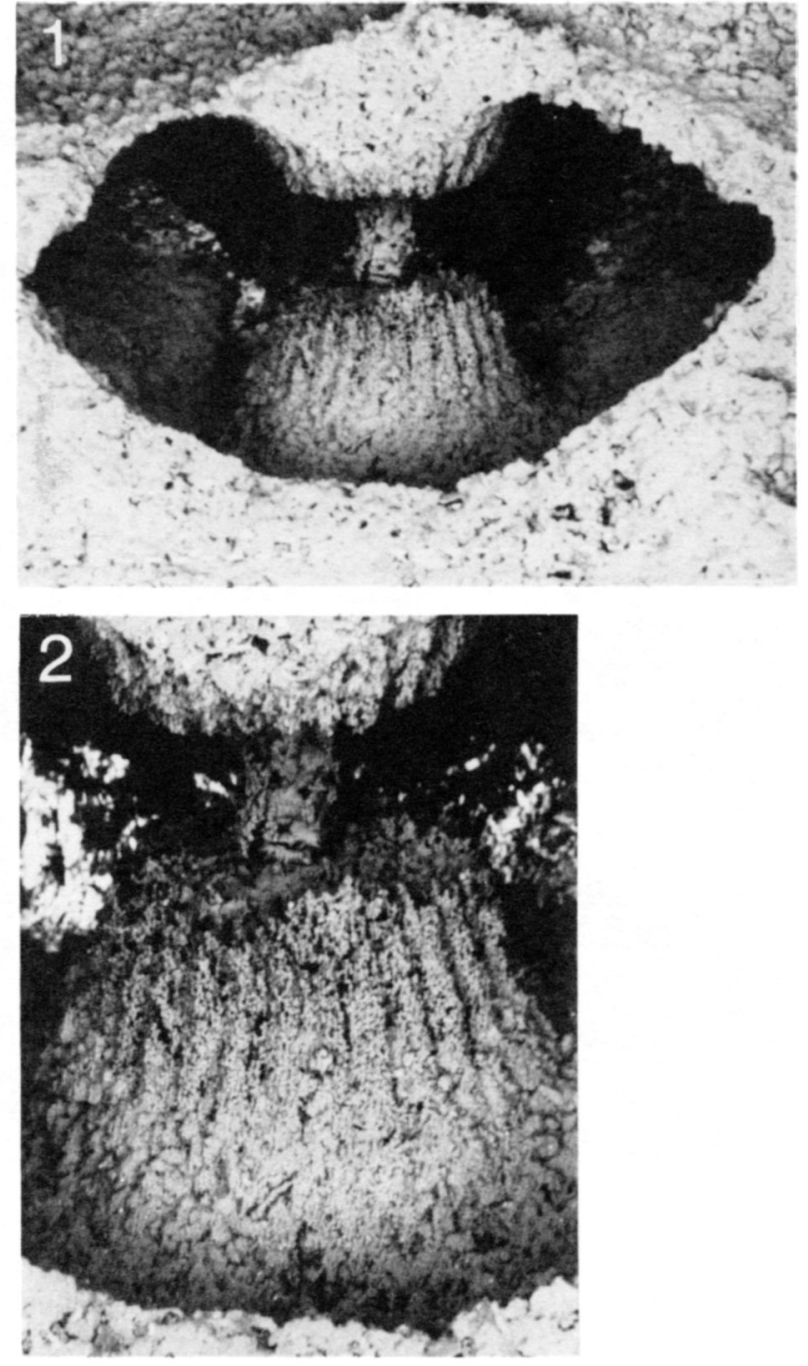

Plate 1. Hexacrinites? (col.) pentastellatus n. sp., [SEM stub \#1, ex-block \#1], paratype (NFM F-302), external mould of columnal. (1) Lateral view of mould, showing lensoid section, crenulae on conical facet and infill of slender axial canal, x24. (2) Detail of crenularium and infill of axial canal, $\times 30$. SE micrographs of a specimen coated with $60 \%$ gold-palladium.

mian (Arendt and Pavlova, 1969; Donovan and Clark, 1992). Nevertheless, as peculiar as this epifacet configuration may be, the best indications of affinity are probably provided by the geometry of the articular facet (Donovan, 1986). Amongst the distinctive features shown by this species are the occurrence of the facet in a depression, into which the crenularium inclines; the depressed areola; the narrow perilumen; and the very small lumen (see below). This combination of features is unusual and is suggestive of certain of the columnals that Russian authors (see, for example, Dubatolova, 1964, 1971) have assigned to the monobathrid genus Hexacrinites Austin and Austin, which is otherwise known from more complete specimens (Ubaghs, 1978b). Indeed, certain Russian species of Hexacrinites also have convex latera (see, in particular, the specimens figured as Hexacrinites(?) mamillatus Yeltysheva and J. Dubatolova by Dubatolova et al., 1967, plate 1), although not having the strongly pentastellate out- 


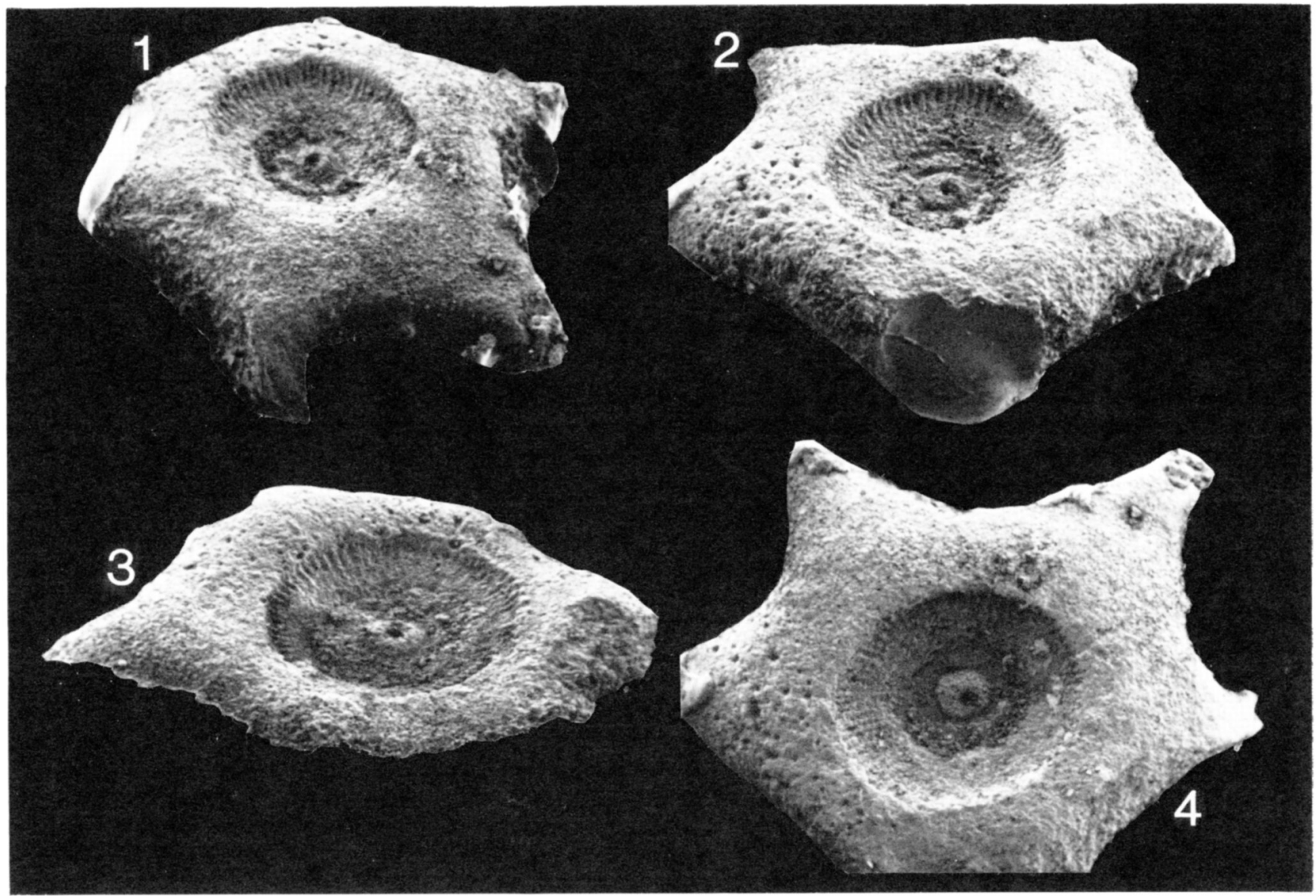

Plate 2. Hexacrinites? (col.) pentastellatus n. sp. (1, 2, 4) [Block \#2, col. B], holotype (NFM F-301), three views of articular facet and pentastellate epifacet, all x7. (3) [Block \#2, col. C], paratype (NFM F-303), oblique view of imperfectly preserved facet, x6. SE micrographs of latex casts coated with $60 \%$ gold-palladium.

line of the Newfoundland species. The distinctive outline of the Newfoundland species and its consistently depressed facet separate it from those described by Russian authors.

Hexacrinites? (col.) pentastellatus $\mathrm{n}$. $\mathbf{s p}$.

Plate 1.1 and .2; Plate 2.1 to .4

Etymology: From Greek pente, five, and Latin stella, star.

Material: Holotype, NFM F-301. Paratypes, NFM F-302, NFM F-303. All specimens from the type locality.

Locality and horizon: The fossil occurrence (91F001) is on the west side of the Bay D'Espoir Highway (Route 360; Fig. 1) approximately $6.5 \mathrm{~km}$ south of the road bridge over the Northwest Gander River. The map reference is NTS map area 2D/11 Eastern Pond, and the grid reference is 611300 5375900 . The fossils are found within a $12-\mathrm{cm}$-thick bed of calcareous, fine grained sandstone that forms part of a $2-\mathrm{m}$ thick sequence composed mainly of weakly cleaved, steeply dipping, thin- to medium-bedded, grey siltstone and sandstone. This sequence has previously been considered to be Middle Ordovician (Colman-Sadd, 1985).
Diagnosis: Moderately large, inflated, pentastellate pelmatozoan columnals (nodals?) with a central, circular, depressed articular facet, comprised of a truncated conical to bowl-like crenularium, a depressed, circular areola, a raised perilumen and a short, slender axial canal of pentagonal section.

Description: Articular facet circular in outline, strongly depressed, either truncated conical (Plate 1) or bowl-like (Plate 2). Articulation symplectial, with numerous, fine, unbranched crenulae sloping radially towards centre of facet. Areola circular and depressed (best seen in Plate 2.4). Small, raised, unsculptured perilumen developed. Lumen small, central and pentagonal. Axial canal within columnal short and straight in columnals with truncated conical facets (Plate 1); even shorter in larger columnals with more bowl-like facets. Columnals moderately high, with broad, inflated, pentastellate latera (Plate 2) that are otherwise unsculptured.

Remarks: The functional morphology of these columnals indicates that they must have been nodals in a heteromorphic column. The arrangement of the crenularium in the depressed facet would have prevented efficient articulation between two columnals of the illustrated morphology. Therefore, 
there must have been smaller internodals, lacking such robust epifacets, intercalated between these pentastellate columnals, which were thus nodals or nodals plus low order internodals (priminternodals, etc.) (see, for example, Donovan, 1989 , text-figure 40). Such an arrangement of plates is found in other pluricolumnals with strongly stellate latera such as Silurian Floricolumnus (col.) girvanensis (see Donovan and Clark, 1992, plate 1, figure 6). Further, the differentiation of depressed facets into truncated conical and bowl-like may indicate that these columnals may come from different parts of the column, probably more proximally and more distally, respectively. If this interpretation is correct, then resorption of calcite during growth would be necessary for the proximal morphology to grow into the distal. It is also possible, perhaps probable, that the column would become more flexible more distally as the slope of the depressed nodal facets lessened. The precise function(s) of the strongly stellate epifacets is uncertain. They may have been at least partly protective; however, as predation would presumably have concentrated on the crown (Lane, 1984) this interpretation is, at best, speculative. A function related to attachment may be more probable (see discussion in Donovan and Clark, 1992).

\section{Discussion}

The information that these columnals provide concerning the age of this deposit is highly suggestive. Hexacrinites Austin and Austin is known to range from the Late Silurian to the Late Devonian, and possibly into the Carboniferous (Webster, 1977 , p. $202 ; 1993$, p. 68), with a cosmopolitan distribution. Whether this indicates that $H$.? (col.) pentastellatus is Silurian or Devonian, or perhaps earlier, is, at best, debatable. However, whether this species represents Hexacrinites sensu stricto or not, what is certain is that columnals combining the morphological features of the articular facet seen in $H$.? (col.) pentastellatus, and other columnal morphotaxa assigned to Hexacrinites, are unknown from the Ordovician (see, for example, Donovan, 1986, 1989, 1995 and references therein). Therefore, $H$.? (col.) pentastellatus indicates an unequivocal post-Ordovician, Palaeozoic age for this locality; on the basis of the copious data published by Russian authors concerning similar columnal morphologies (Dubatolova, 1964, 1971; Dubatolova et al., 1967; amongst others), this is almost certainly Late Silurian or Devonian.

Supporting data is provided by brachiopods from the same locality. Moderately large brachiopod cross-sections from a block of talus (NGS [5]) resembles a number of pentameroid genera. These include:

Brooksina Kirk, 1922 (Family PENTAMERIDAE M'Coy, 1844: Subfamily PENTAMERINAE M'Coy, 1844), known from the Late Silurian (Ludlow) of Alaska (Kirk, 1922; Kirk and Amsden, 1952) and Nevada (Johnson et al., 1976), Russia (Amsden and Biernat, 1965, p. H547), Asia and Australia (Rong et al., 1995);

Gypidula Hall, 1867 (Family GYPIDULIDAE Schuchert and LeVene, 1929: Subfamily GYPIDULINAE Schuchert and
LeVene, 1929), Early Silurian to Late Devonian (Jin et al., 1993, pp. 32-33; Rong et al., 1995);

Gypidulina Rzhonsnitskaya, 1956 (Family GYPIDULIDAE Schuchert and LeVene, 1929: Subfamily SIEBERELLINAE Sapelnikov, 1973), Early Silurian to Early Devonian (Jin et al., 1993, pp. 35-36); and

Clorinda Barrande, 1879 (Family CLORINDIDAE Rzhonsnitskaya, 1956), Early Silurian to Early Devonian (Jin et al., 1993, pp. 37-39; Rong et al., 1995).

According to Bassett $(1989$, p. 239), during the late Ludlow (approximately Ludfordian Stage) there was a rapid, shortlived radiation of ribbed pentameride genera including Brooksina. Most of these became reduced or extinct at the end of the Ludlow, along with many other pentameraceans (Bassett, 1989, p. 241). The presence of pentameroid brachiopods is at least suggestive of a Late Ordovician to Devonian age (e.g., Amsden and Biernat, 1965, p. H541, figure 4-11). The extension of the length of the valve by the median septum, seen in these specimens, is a diagnostic feature of Brooksina: other genera listed above, when of comparable size $(1.7 \mathrm{~cm})$, do not contain a continuous median septum. Thus the occurrence of pelmatozoan columnals assigned to Hexacrinites in association with Brooksina strongly suggests a Late Silurian (or even Devonian) age.

\section{ACKNOWLedgements}

We thank Mr. Cornelis J. Veltkamp (University of Liverpool) for taking the SE micrographs. Incisive review comments by Professors William I. Ausich (Ohio State University), S. Henry Williams (Memorial University of Newfoundland) and Christopher R.C. Paul (University of Liverpool) are gratefully acknowledged.

Amsden, T.W. and Biernat, G. 1965. Pentamerida. In Treatise on Invertebrate Paleontology, Part H, Brachiopoda (2). Edited by R.C. Moore. Geological Society of America and University of Kansas Press, New York and Lawrence, pp. H523-H552.

Anderson, F.D. and Williams, H. 1970. Gander Lake (West Half), Newfoundland. Geological Survey of Canada, Map 1195A.

ARENDT, Yu.A. and PAVLOVA, YE.YE. 1969. Characteristics of Orocrinus. Paleontological Journal, Number 2 for 1969, pp. 231-236. [Translated from Russian.]

Austin, T. and Austin, T., JR. 1843. Description of several new genera and species of Crinoidea. Annals and Magazine of Natural History, Series 1, 11, pp. 195-207. [Not seen.]

Barrande, J. 1879. Systême silurien du Centre de la Bohême. Première Partie: Recherches Paléontologiques, v. 5, Classe des Mollusques, Ordre des Brachiopodes, 226 p.

Bassett, M.G. 1989. Brachiopods. In A global standard for the Silurian System. Edited by C.H. Holland and M.G. Bassett. National Museum of Wales, Geological Series, Number 9 , pp. 232-242.

Bengston, P. 1988. Open nomenclature. Palaeontology, 31, pp. 223-227.

Billings, E. 1874. Palaeozoic fossils. Volume 2, part 1. Geological Survey of Canada, 144 p.

BLACKwood, R.F. 1982. Geology of the Gander Lake (2D/15) and Gander River (2E/2) area. Newfoundland Department of Mines and Energy, Mineral Development Division, Report 82-4. 
---- 1983. Notes on the Geology of the Great Gull River map area (2D/6), Newfoundland. Newfoundland Department of Mines and Energy, Mineral Development Division. Accompanies Map 82-71.

BOYCE, W.D. 1987. Cambrian-Ordovician trilobite biostratigraphy in central Newfoundland. In Current Research. Newfoundland Department of Mines and Energy, Mineral Development Division, Report 87-1, pp. 335-341.

Boyce, W.D. and Ash, J.S. 1994. New Silurian Devonian(?) faunas from the Gander (NTS 2D/15) and Botwood (NTS 2E/ 3) map areas. In Current Research. Newfoundland Department of Mines and Energy, Geological Survey Branch, Report 94-1, pp. 53-63.

Boyce, W.D., Ash, J.S., O'Neill, P., and Knight, I. 1988. Ordovician biostratigraphic studies in the Central Mobile Belt and their implications for Newfoundland tectonics. In Current Research. Newfoundland Department of Mines and Energy, Mineral Development Division, Report 88-1, pp. 177-182.

Boyce, W.D., Ash, J.S., and Colman-SADD, S.P. 1993a. Trilobite-based age determination of the Riches Island Formation (Baie D'Espoir Group) in the St. Alban's map area (NTS $1 \mathrm{M} / 3$ ), central Newfoundland. In Current Research. Newfoundland Department of Mines and Energy, Geological Survey Branch, Report 94-1, pp. 181-185.

Boyce, W.D., Ash, J.S., and Dickson, W.L. 1993b. The significance of a new bivalve fauna from the Gander map area (NTS 2D/15) and a review of Silurian bivalve-bearing faunas in central Newfoundland. In Current Research. Newfoundland Department of Mines and Energy, Geological Survey Branch, Report 93-1, pp. 187-194

Colman-SADD, S.P. 1985. Geology of the Burnt Hill map area (2D/5) area. Newfoundland Department of Mines and Energy, Mineral Development Division, Report 85-3

Colman-SADD, S.P. and Russell, H.A.J. 1988. Miguels Lake (2D/ 12), Newfoundland. Newfoundland Department of Mines and Energy, Mineral Development Division, Map 88-50.

Colman-SADD, S.P. and Swinden, H.S. 1984. A tectonic window in central Newfoundland? Geological evidence that the Dunnage Zone may be allochthonous. Canadian Journal of Earth Sciences, 21 , pp. 1349-1367.

Dec, T. and Colman-SADD, S.P. 1990. Timing of ophiolite emplacement onto the Gander Zone: evidence from provenance studies in the Mount Cormack Subzone. Department of Mines and Energy, Geological Survey Branch, Report 90-1, pp. 289303.

Dickson, W.L. 1992. Ophiolites, sedimentary rocks, posttectonic intrusions and mineralization in the Eastern Pond (NTS 2D/ 11 W) map area, central Newfoundland. In Current Research. Newfoundland Department of Mines and Energy, Geological Survey Branch Report 92-1, pp. 97-118.

Donovan, S.K. 1986. Pelmatozoan columnals from the Ordovician of the British Isles, part 1. Palaeontographical Society Monographs, London, 138, part 568, pp. 1-68.

---- 1989. Pelmatozoan columnals from the Ordovician of the British Isles, part 2. Palaeontographical Society Monographs, London, 142, part 580, pp. 69-114.

...- 1995. Pelmatozoan columnals from the Ordovician of the British Isles, part 3. Palaeontographical Society Monographs, London, 149, part 597, pp. 115-194.

Donovan, S.K. and CLARK, N.D.L. 1992. An unusual crinoid columnal morphospecies from the Llandovery of Scotland and Wales. Palaeontology, 35, pp. 27-35.
Dubatolova, Yu.A. 1964. [Devonian crinoids of the Kuznetsk Basin.] Trudy Akademii nauk SSSR, Sibirskogo Otdeniye Instituta Geologii i Geofiziki, 124 p. [In Russian.]

-... 1971. [Crinoidea of the Early and Middle Devonian of the Altai and Kuzbas.] Trudy Akademii nauk SSSR, Sibirskogo Otdeniye Instituta Geologii i Geofiziki, 124, 159 p. [In Russian.]

Dubatolova, Yu.A., Yeltysheva, R.S., and Modzalebskaya, Y.A. 1967. [Sea lilies from the Devonian and Lower Carboniferous of Dal'nego Vostoka.] Trudy Akademii nauk SSSR, Sibirskogo Otdeniye Instituta Geologii i Geofiziki, 72 p. [In Russian.]

Dunning, G.R., O'Brien, S.J., Colman-Sadd, S.P., Blackwood, R.F., O'Neill, P.P., Dickson, W.L., and KROGH, T.E. 1990. Silurian orogeny in the Newfoundland Appalachians. Journal of Geology, 98, pp. 895-913.

Hall, J. 1860. Descriptions of new species of fossils from the Silurian rocks of Nova Scotia. Canadian Naturalist and Geologist, 5, pp. 144-159.

---- 1867. Descriptions and figures of the fossil Brachiopoda of the Upper Helderberg, Hamilton, Portage and Chemung groups. New York Geological Survey, Paleontology of New York, 4:1, $428 \mathrm{p}$.

JiN, J., Caldwell, W.G.E., and Norford, B.S. 1993. Early Silurian brachiopods and biostratigraphy of the Hudson Bay Lowlands, Manitoba, Ontario and Quebec. Geological Survey of Canada, Bulletin 457, $221 \mathrm{p}$

Johnson, J.G., Boucot, A.J., and Murphy, M.A. 1976. Wenlockian and Ludlovian age brachiopods from the Roberts Mountains Formation of central Nevada. University of California Publications in Geological Sciences, 115, 101 p.

KIRK, E. 1922. Brooksina, a new pentamerid genus from the Upper Silurian of S.E. Alaska. Proceedings of the United States National Museum, 60, pp. 1-8.

KiRK, E. and AMSDEN, T.W. 1952. Upper Silurian brachiopods from southeastern Alaska. United States Geological Survey, Professional Paper 233-C, pp. 53-66.

Lane, N.G. 1984. Predation and survival among inadunate crinoids. Paleobiology, 10, pp. 453-458.

M'Coy, F. 1844. A synopsis of the Carboniferous Limestone fossils of Ireland. Dublin, $207 \mathrm{p}$.

McLearn, F.H. 1924. Palaeontology of the Silurian rocks of Arisaig, Nova Scotia. Geological Survey of Canada, Memoir 139, $180 \mathrm{p}$.

Moore, R.C., Jeffords, R.M., and Miller, T.H. 1968. Morphological features of crinoid columns. University of Kansas Paleontological Contributions, Echinodermata Article 8, 30 p.

Phillips, J. 1841. Figures and descriptions of the Palaeozoic fossils of Cornwall, Devon, and west Somerset. Longman, Brown, Green and Longmans, London, 232 p. [Not seen.]

Pisera, A. 1994 . Echinoderms of the Mojcza Limestone. In Ordovician carbonate platform ecosystem of the Holy Cross Mountains. Edited by J. Dzik, E. Olempska and A. Pisera. Palaeontologia Polonica, 53, pp. 283-307.

Rong, J.-Y., Boucot, A.J., Su, Y.-Z., and Strusz, D.L. 1995. Biogeographical analysis of Late Silurian brachiopod faunas, chiefly from Asia and Australia. Lethaia, 28, pp. 39-60.

Rzhonsnitskaya, M.A. 1956. Semeystvo Pentameridae i semeystvo Camarotoechiidae. In Atlas rukavodyashchikh form iskopaemykh fauny i flori zapadnoi Sibiri. Edited by V.K. Khalfina, pp. 53-55.

SAPELNIKOV, V.P. 1973. Novye taksonomicheskiye gruppy $v$ otryade Pentamerida: Brakiopody. Akademiya Nauk SSR, Institut 
Geologii i Geokhimii, Uralskiy Nauchnyy Tsentr, Ezhegodnik 72 , pp. $39-41$.

Schuchert, C. and Levene, C.M. 1929. New names for brachiopod homonyms. American Journal of Science, 17, pp. 119-122.

Stukalina, G.A. 1968. On the systematics of the Pentamerata (Crinoidea) group. Paleontological Journal, No. 1 for 1968, pp. 73-82. [Translated from Russian.]

Ubaghs, G. 1978a. Skeletal morphology of fossil crinoids. In Treatise on Invertebrate Paleontology, Part T, Echinodermata 2(1). Edited by R.C. Moore and C. Teichert. Geological Society of America and University of Kansas Press, Boulder and Lawrence, pp. T58-T216.

-.-- 1978b. Camerata. In Treatise on Invertebrate Paleontology, Part T, Echinodermata 2(2). Edited by R.C. Moore and C. Teichert. Geological Society of America and University of Kansas Press, Boulder and Lawrence, pp. T408-T519.

Webster, G.D. 1977. Bibliography and index of Paleozoic crinoids 1969-1973. Geological Society of America, Microform Publication 8,235 p.
-..- 1993. Bibliography and index of Paleozoic crinoids 19861990. Geological Society of America, Microform Publication 25, $204 \mathrm{p}$.

Williams, H. 1972. Stratigraphy of Botwood map-area, northeastern Newfoundland. Geological Survey of Canada, Open File 113,103 p.

Williams, S.H. 1991. Graptolites from the Baie D'Espoir Group, south-central Newfoundland. In Current Research. Newfoundland Department of Mines and Energy, Geological Survey Branch, Report 91-1, pp. 175-178.

-..-- 1993. More Ordovician and Silurian graptolites from the Exploits Subzone. In Current Research. Newfoundland Department of Mines and Energy, Geological Survey Branch, Report 93-1, pp. 311-315.

Williams, S.H., Boyce, W.D., and Colman-SadD, S.P. 1992. A new Lower Ordovician (Arenig) faunule from the Coy Pond Complex, central Newfoundland, and a refined understanding of the closure of the Iapetus Ocean. Canadian Journal of Earth Sciences, 29, pp. 2046-2057. 